\section{Portrette in my gang.}

Dolf van Niekerk. Pretoria:

Protea Boekhuis, 2015.

ISBN 978-1-4853-0230-8 (gedrukte boek); ISBN 978-1-4853-031-5 (e-boek); ISBN 978-1-4853-0482-1 (ePub).

DOI: http://dx.doi.org/10.17159/tvl.v.54i1.26

Portrette in my gang van die Afrikaanse veteraanskrywer Dolf van Niekerk volg op sy vorige bundel, Bleek planeet (2013), ook uitgegee deur Protea Boekhuis. As digter het Van Niekerk, wat groot bekendheid verwerf het as ' $n$ baanbrekende eksperimentele prosaskrywer van Sestig, reeds Karoosange (1975), Dubbelster (1996), Nag op ' $n$ kaal plein (2006) en Lang reis na Ithaka (2009) die lig laat sien.

Uit alleen die titels van sy digoeuvre kan reeds veel van hierdie digter se bemoeienisse, wat in Portrette in my gang verder gevoer word, gesien word. Daar is 'n gemoeidheid met die skending van die natuur, wat spruit uit die digter se aanvanklike landelike geworteldheid en ook sy werk as landboukundige.

'n Belangstelling in die naat tussen beskawing en natuur, alternatiewelik instink en rede kan verder afgelees word uit die metaforiese lading in ' $\mathrm{n}$ titel soos Nag op 'n kaal plein (wat, terloops, herinner aan die titel van Bernlef se skitterende Nederlandse vertalings van die Sweedse Nobelprysdigter Tomas Tranströmer, Het wilde plein).

Van Niekerk se belangstelling in die klassiek -in die huidige bundel te vinde in gedigte soos "Steppenwolf" (15), "nobilis" (11), “Gioconda" (12), om enkeles te noem-kan ook gesien word in die titel van sy bundel Lang reis na Ithaka, wat heenwys na die verhaal van die klassieke held Odusseus, en ook na 'n latere gedig van die Grieks-Alexandrynse digter C. P. Kavafis, "Ithaka", wat insgelyks handel oor Odusseus.

Juis laasgenoemde digter se korpus, wat in besonderhede handel oor die tema van bloei en verval van kulture en beskawings, bring my by Van Niekerk se eie hantering van hierdie tema in Portrette in my gang, te vinde in gedigte soos "voltooide kring" (14) en "Wiederkehr" (16), wat na Nietzsche, die vader van die einde van die Europese beskawing as 'n gestruktureerde projek, se begrip van die "ewige wederkeer" verwys_'n tema wat by implikasie ook aangesny word in Kafavis se genoemde gedig. Aangesien ' $n$ mens altyd lees vanuit jou eie tydsgewrig, en die voordele van tydsverloop tot jou beskikking het, kan'n mens die genoemde tema van Nietzsche selfs in ' $n$ hedendaagse lees van Homeros se epos Die odusseia, raaklees.

Nog gedigte in Portrette in my gang wat hierby aansluiting vind, is onder andere "Die profeet van Omsk" (21), wat handel oor die Russiese skrywer, Dostojefski; “Tel Aviv 1987" (23), "Wind" (24) (oor "die winde van verandering"); "Mediaan" (36); en "Mutant" (46).

Hierdie opmerkings van my is bedoel om die leser se aandag daarop te vestig dat ons in Dolf van Niekerk' $n$ digter het wat ten nouste omgaan met bepaalde "groot" temas, wat ook reeds deur 'n digter soos N. P. Van Wyk Louw in Afrikaans gevestig is.

Die bundel word nie, soos Van 
Niekerk se vorige bundel, ingedeel in onderafdelings nie, Die implikasie hiervan is dat dit hier, metafories gesproke, één "gang" is waarby die digter as individu "af loop" en bestek opneem, sy eie lewensgang, as't ware, en die "portrette" wat "daar hang" is sy persoonlike huldeblyke, mymeringe en spirituele sorge en versorgings van 'n lewe.

Die genoemde "portrette" sluit in jeugherinneringe, soos "Verhuising" (28), oor vermoedelik'n pa se sterfte, "Oestyd" (29), "Swartberg (30) en “Circa 1933" (55); gedigte oor skrywers soos Hermann Hesse (die genoemde "Steppenwolf"), Van Wyk Louw ("voltooide kring"), en oor filosowe soos Herakleitos, Albert Schweizer ("Prelude en fuga", 51) en andere.

' $n$ Verdere bemoeienis van die bundel is die kwessie van geheue, persoonlik en ook kulturele geheue, en geheue van die aarde; en die verganklikheid waaraan die verskillende vorme van geheue blootgestel word. Hierdie soort vernieling en verlies is iets wat die sinmaking van die mens van sy eie lewe ten nouste raak. Die uitkyk hierop in die bundel is melankolies: "Mutasie is bloot oorgang / van arbitrêr ontstaan na ondergang" ("Mutant", 46).

In "Tablet" (35) mymer die digter oor die verdwyning van Gondwanaland, en in "Oestyd" is daar 'n verwysing na Atlantis, die mitiese stad van die een of ander Oudheid, wat na bewering onder die see verdwyn het. Hierdie verganings het implikasies vir die ouerwordende digter self, soos sy bewoë oproep van gestorwernes, en sy herinneringe aan die dinge wat vir hom verbygegaan het, wys. ("Selfportret", 62; "Jaargety", 42; "Krui", 39; en "Swartberg", 30).

'n Opvallende en baie mooi vers is "langs die see" (57), waarin die motief van die wind, wat in ander gedigte in die bundel ook voorkom, figureer. Die wind is uitwisser van spore ("geheue") maar óók vertrooster, soos in "Venster" (47). Die pragtige gedig "Nagwind", wat eggo's van A. Roland Holst sowel as van N. P. Van Wyk Louw bevat, eindig met die resonante reëls: "Nag by die see,/ om my huisie lê die wind".

Een van die effekte wat die bundel op hierdie leser gehad het, was op die metafisiese vlak_'n vlak waaroor sommige van die verse pertinent handel, of dit nou gaan oor die filosofie, of die primordiale (die voorafgaande en agterliggende) geskiedenis, of oor die implisiete betekenis van ervarings soos in die genoemde "Venster". Hierdie leser is dikwels, veral by die herlees, herinner aan die kreatiewe spanning al dan nie, wat die gedigte met die outeur se digterlike of filosofiese ewekniëe of tydgenote in Afrikaans het.

"Venster" begin met dié reëls: "agter brandglas van twaalf kleure / roer onbekende blaarpatrone". Dis 'n mooi toespeling, waarin brandglas die religieuse kerkbelewenis betrek, en die blare na die wilde natuur daar buite verwys. Ek het reeds gepraat van die bundel se spanning tussen denke en instink, en in hierdie gedig kom 'n soortgelyke spanning, 'n iterasie op dieselfde tema, voor, naamlik die spanning tussen die natuur en die geloof. 
Die genoemde gedig ("Venster") los nie die spanning op, soos byvoorbeeld gevind word by T. T. Cloete in die deurtrek by laasgenoemde van patrone of motiewe in die lewe na "groter patrone" en motiewe in die natuur en in die evolusie, om na bewering die groot samehang in die Skepping van die "Onbekende Kunstenaar" (Van Niekerk se term vir God) te toon. By Van Niekerk is daar nie ' $n$ samehang of sluiting van teenstellings nie soos Cloete dikwels verdig en dikwels baie goed; die spanning word nie opgelos nie; dit word gelate aanvaar in wat lyk na'n nederige, agnostiese oorgawe ("Visbaai", 59, my kursivering).

En in "Paradigma": "En elke geslag / sal telkens 'n kopskuif maak / tot metafoor vir die groot verlange." (Daar is vele agnostiese benaderings, dis nie alles dieselfde nie. Ek verwys met dié woord na 'n geloof wat homself weerhou daarvan om enige vorm toe te dig aan God, of vormgewing by ' $n$ minimum hou.) In "Steppenwolf" staan daar gewoon: "godheid [is] tuiste vir die uithuisige enkeling" (15)

"Visbaai" eindig met 'n beskrywing van Bartolomeu Dias, hy wat soms 'n padrão (klipkruis ter ere van God) aan die kuste geplant het en soms nie, en wat sal terugkeer na "die Taag", waar hy "net nuwe name kan noem / op sy vaart na êrens" (my kursivering).

Trouens, hierdie "agnostisiese" aspek is vir my by Van Niekerk juis 'n spieëlbeeld van sy eksistensialisme as skrywer. In "Selfportret" (62) beskryf die digter die vormgewing van sy eie gesig by die maak van ' $n$ selfportret as ' $n$ eksistensialistiese "enigma", en homself as iets wat nie eintlik kan ken nie. In "Circa 1933" (55) staan daar verder: "die eintlike gebeure lê diep verborge / deur almal beleef, deur niemand waargeneem" (my kursivering).

Nog 'n meta-aspek wat deur die bundel gekommunikeer word, is die tema van betekenis en betekenisgewing, wat afgelees kan word uit gedigte soos die genoemde "Visbaai", "Langs die see"; en "laaste woord", onder andere.

In "Monsters" (33), 'n treffende gedig, word die middelmatigheid bekla van nuwe generasies wat tevrede is met middelmatigheid en wat berus by "die geeslose", en in "Sin is" (32) word sinvolheid beskryf as die transformasie van dierlikheid, terwyl geestelikheid beskryf word as die soeke na betekenis. Dit herinner baie aan die filosoof George Steiner se siening iewers, dat die enigste onverganklike menslike strewe die soeke na betekenis is.

Maar is dit noodwendig so? Is betekenissoeke noodwendig die hoogste sinvolheid? Die bundel gee blyke van twyfel hieraan in "Mutant" en "Venster", byvoorbeeld.

Dis ingrypende nadenke wat sommige van hierdie gedigte by die leser stimuleer. En tog het ek besware teen die bundel as digterlike produk. Die sinskonstruksie is dikwels verduisterend. Dit lyk soms of daar 'n verwarrende gebruik is van leestekens. Die gebruik van die kommapunt en die aandagstreep is goeie voorbeelde hiervan. Die fragmentstyl van opeengestapelde sinsnedes veroorsaak 
dat die sinvolheid van die sin self verlore raak-soos in die een na die ander sinsnede tussen kommapunte wat op mekaar volg.

Die toon van die gedigte is dikwels "toonloos", of eentonig. Toonaard en "stem" is een van die belangriker elemente van'n geslaagde gedig, en daar is te min van 'n "stem" in die gedigte. Soms is die beelding ook verward. Sommige van die titels verskyn sonder enige rede alles in klein letters, terwyl dit nie die oorwegende styl van die bundel is nie.

Daar is min van Dolf van Niekerk, die eksperimentele vernuwer in die prosa, in hierdie bundel gedigte te sien. Wat styl betref skep die bundel oor die algemeen 'n verslete, konvensionele indruk.

En tog kan ek die lees hiervan aanbeveel, vir al die redes wat hoër op uit my resensie behoort te blyk. Daar is plekplek werklik pragtige reëls, soos: "Ek, grys en verleë,/ vlieg in "n droomreën op" $^{\prime \prime}(57)$.

In "Skêrsang" (52) word 'n skaapskeerdery beskryf waarin die geskeerde ooitjie "haelwit in die kraaltjie spring" en die skaapskeerder word besonder treffend beskryf as ' $n$ "Michelangelo van die marmerskaap". Dis 'n pragtige gedig, wat ongelukkig ook ontsier word deure enkele oortollige reëls in die eerste gedeelte.

Dolf van Niekerk se nuutste bundel sal veral tot sy reeds bekeerde groep lesers spreek.

\section{Charl-Pierre Naudé}

charlpierren@gmail.com 